Ekonomia - Wroclaw Economic Review 27/3 (2021)

Acta Universitatis Wratislaviensis

No 4081

https://doi.org/10.19195/2658-1310.27.3.2

Agata Niemczyk

ORCID: 0000-0002-5594-6296

Podhalańska Państwowa Uczelnia Zawodowa w Nowym Targu

agata.niemczyk@ppuz.edu.pl

Paweł Zamora

ORCID: 0000-0001-8856-684X

Podhalańska Państwowa Uczelnia Zawodowa w Nowym Targu

pawel.zamora@ppuz.edu.pl

\title{
Interwencjonizm państwowy na rynku usług turystycznych w warunkach pandemii COVID-19
}

Artykuł nadesłany: 31.08.2021; artykuł zaakceptowany: 19.09.2021

Kody klasyfikacji JEL: A10, Z31, Z33

Keywords: tourism, COVID 19, state intervention, government shield, tourist voucher

\begin{abstract}
State interventionism in the tourist services market in the conditions of the COVID-19 pandemic

Of the many industries, the travel industry has been hit hardest by the COVID-19 pandemic. Entities supplying the tourist market remained closed for almost a year, not conducting their activities. In such a situation, the mechanisms of state intervention come in handy and the set of their tools includes anti-crisis shields as well as a tourist voucher.

The aim of the article is to present the scale of the impact of the COVID-19 pandemic on tourism activity in Poland and the scale of state intervention in this industry. The article is of theoretical and analytical character. Research methods typical of this type of studies were used: critical analysis of the literature on the subject, analysis of documents, analysis of published secondary data.
\end{abstract}

\section{Abstrakt}

Spośród wielu branż turystyczna została w największym stopniu dotknięta skutkami pandemii COVID-19. Podmioty podaży rynku turystycznego blisko rok pozostały zamknięte, nie prowadząc 
swojej działalności. Pomocne w takiej sytuacji są mechanizmy interwencjonizmu państwowego, a w zbiorze ich narzędzi tarcze antykryzysowe oraz bon turystyczny.

Celem artykułu jest zaprezentowanie skali wpływu pandemii COVID-19 na działalność turystyczną w Polsce oraz skali interwencjonizmu państwowego w tej branży. Praca ma charakter teoretyczno-analityczny. Wykorzystano typowe w takich opracowaniach metody badawcze: krytycznej analizy literatury przedmiotu, analizy dokumentów, analizy publikowanych danych wtórnych.

Slowa kluczowe: turystyka, COVID 19, interwencjonizm państwowy, tarcza rządowa, bon turystyczny

\section{Wstęp}

Turystyka jest jednym z głównych sektorów gospodarki na świecie. W 2019 roku odpowiadała za 10,3\% światowego PKB. Rok 2020 okazał się trudny dla wielu branż gospodarczych, także dla branży turystycznej. Czas pandemii COVID-19 dowiódł konieczności podejmowania niestandardowych działań w zakresie polityki makroekonomicznej. Interwencje państwa w gospodarce stały się koniecznością. Asymetryczne oddziaływanie kryzysu gospodarczego na poszczególne segmenty gospodarki powodowało, że niektóre z nich ucierpiały w wyniku pandemii najwięcej. Artykuł prezentuje skalę wpływu pandemii na światowy rynek turystyczny, ze szczególnym uwzględnieniem rynku polskiego, oraz mechanizmy odziaływania państwa w zależności od potrzeb gospodarki, w kontekście rynku usług turystycznych w warunkach pandemii COVID-19. Rozważania podjęte w pracy mają charakter teoretyczno-analityczny; wykorzystano typowe w takich opracowaniach metody badawcze: krytycznej analizy literatury przedmiotu, analizy publikowanych empirycznych danych wtórnych.

\section{Rynek usług turystycznych w czasach COVID-19}

Turystyka jest jednym z głównych sektorów gospodarki na świecie. Jest trzecią co do wielkości dziedziną eksportu (po paliwach i chemikaliach), a w 2019 roku stanowiła 10,3\% światowego PKB (UNWTO, 2020A). W 2019 roku odnotowano wzrost światowego PKB sektora turystyki o 3,5\%, większą dynamikę wzrostu odnotował tylko sektor informacji i komunikacji oraz usług finansowych (WTTC, 2020). Również w perspektywie Europy jako kontynentu jej znaczenie jest duże. Sektor turystyki w całej UE w 2019 roku odpowiadał za 9,5\% całkowitego PKB UE, generował 11,2\% miejsc pracy w UE, obejmował 3 mln firm, z których $90 \%$ to MŚP (COVID-19 and the tourism sector..., 2020). W wielu regionach Europy Południowej właśnie ten sektor jest często głównym pracodawcą, zapewniając niezbędne dochody rodzinom i wsparcie dla lokalnych gospodarek. Największymi 
gospodarkami europejskimi, uwzględniając wielkość turystyki w PKB w 2019 roku, były Niemcy (347 mld USD), Włochy (260 mld USD), Wielka Brytania (254 mld USD), Francja (229 mld USD) i Hiszpania (198 mld USD) (WTTC, 2020).

Wszystkie prognozy dotyczące turystyki zapowiadały spektakularny globalny wzrost podróży turystycznych. W 2019 roku zrealizowano ich blisko 1,5 mld, a prognozy na 2030 rok zapowiadały wielkość 1,8 mld (UNWTO, 2011). Niedająca się przewidzieć epidemia, uważana w niektórych źródłach naukowych za czarnego łabędzia cyklu koniunkturalnego (Zelek, 2020; 2021), wywołała recesję, w tym także na rynku turystycznym. Uznaje się (Gołembski, 2020; GUS 2020), że rynek usług turystycznych jest przykładem gałęzi gospodarki, w której odnotowano stosunkowo największe skutki kryzysu pandemicznego. Dane zestawione na rysunku 1 potwierdzają, że pandemia COVID-19 poskutkowała redukcją przyjazdów międzynarodowych na świecie na skalę niewyobrażalną do tej pory, nawet nieporównywalną do kryzysu ekonomicznego w 2009 roku czy wcześniejszej epidemii SARS. Udział turystyki w światowym PKB w 2020 roku spadł o 49,1\% w porównaniu z rokiem poprzednim; z 9,2 bln USD w 2019 roku do 4,7 bln USD rok później. W tym samym czasie cała globalna gospodarka skurczyła się o 3,7\% (Wolska, 2021A). Wskutek zahamowania usług turystycznych zmniejszył się istotnie udział turystyki w światowym PKB. O ile w 2019 roku wyniósł on aż $10,3 \%$, to rok później o połowę mniej, bo $5,5 \%$.

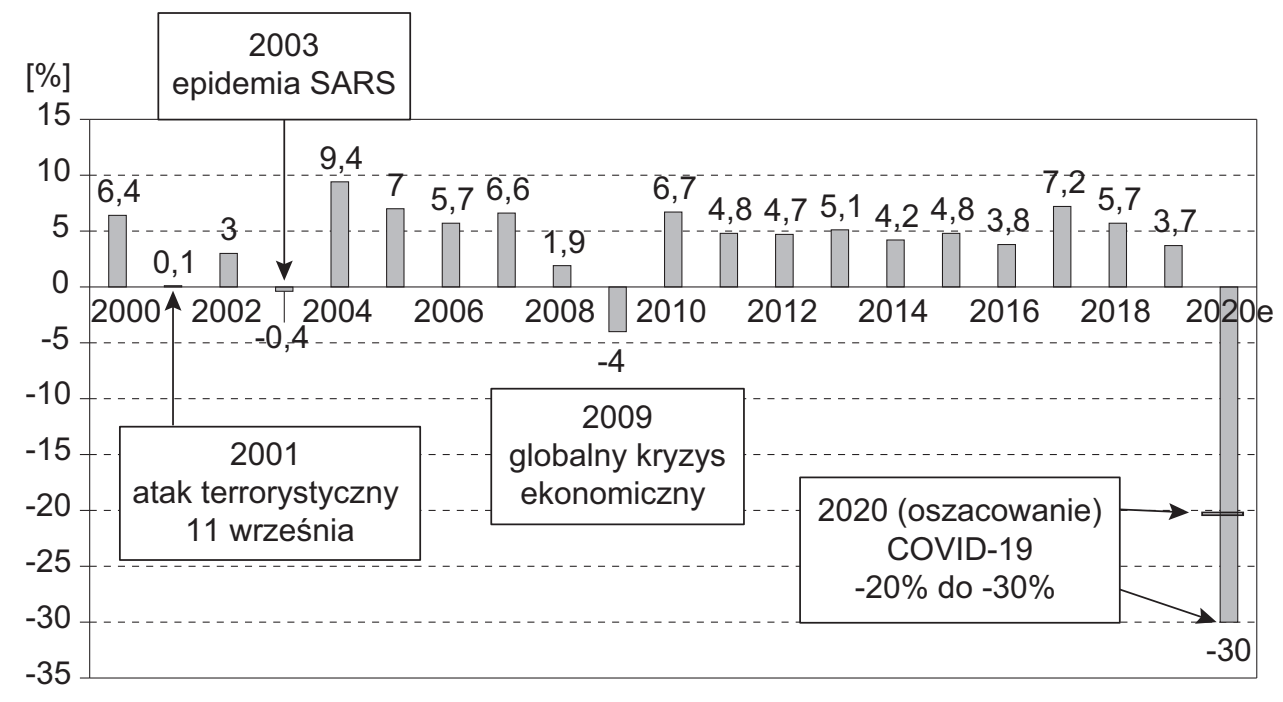

Rysunek 1. Dynamika zmian międzynarodowych przyjazdów turystycznych (zmiana w \%) na tle momentów kryzysowych

Legenda: e-szacunek

Źródło: UNWTO, 2020B. 
Analizując dane dotyczące stanu turystyki w czasie trwania pandemii, kolejną ważną kwestią jest stan zatrudnienia (Marques Santos et al., 2020). W turystyce w 2019 roku zatrudnionych było, według danych WTTC, $334 \mathrm{mln}$ osób, ale już rok później zatrudnienie zmniejszyło się o 18,5\%, co oznaczało, że pracę straciły 62 mln ludzi (Wolska, 2021A). Światowa Organizacja Turystyki (UNWTO) oszacowała spowodowane pandemią COVID-19 ubiegłoroczne straty branży na 1,3 bln dolarów. Pracę stracić w niej miało 100-120 mln osób (Wolska, 2021B).

Odnośnie do warunków polskich w Raporcie Polskiego Instytutu Ekonomicznego opublikowanym w 2020 roku podkreśla się, iż wartość dodana wygenerowana przez branżę turystyczną w 2018 roku wyniosła 1,3\% polskiego PKB i była znacznie niższa niż średnia uzyskiwana przez państwa OECD w wysokości 4,4\% (Branża turystyczna w Polsce, 2020). W turystyce polskiej przeważają podróże krajowe (w 2018 roku było to $80 \%$ ruchu turystycznego) oraz przyjazdy turystów z państw sąsiednich. Turyści zagraniczni wydali w Polsce w 2018 roku 34,5 mld PLN, a krajowi — 27,7 mld PLN. W tymże roku z turystycznych obiektów noclegowych mających 10 lub więcej miejsc noclegowych skorzystało 33,9 mln turystów, a dwa lata później tylko 18,8 mln - o 49\% mniej niż rok wcześniej. W 2020 roku do Polski przyjechało 51,1 mln nierezydentów i było to o 42,3\% mniej niż w roku poprzednim, z tego 8,4 mln turystów (o 60,2 \% mniej niż rok wcześniej) i 42,7 mln odwiedzających jednodniowych (o $36,7 \%$ mniej). Prawie wszyscy turyści zagraniczni (99\%) nocowali w hotelach. W turystycznych obiektach noclegowych pod koniec lipca 2020 roku działało 7195 placówek gastronomicznych (restauracji, barów i kawiarni, stołówek oraz punktów gastronomicznych), czyli o 774 (9,7\%) mniej niż w roku poprzednim (GUS, 2021). W ślad za opisanymi zmianami szły redukcje w zatrudnieniu. To w branży turystycznej zmniejszyło się ono aż o 17,1\%; w hotelach zlikwidowano około 80 tys. miejsc pracy. W ciągu 2020 roku o ponad jedną piątą zwiększyło się średnie zadłużenie biur i agentów turystycznych. Według Ogólnopolskiego Stowarzyszenia Agentów Turystycznych przychody agentów turystycznych w styczniu 2021 roku zmniejszyły się, w porównaniu ze styczniem ubiegłego roku, aż o $82 \%$. Zawieszenie lub zamknięcie działalności rozważa aż 38\% przedsiębiorców z przemysłu spotkań i wydarzeń (Ekspert: turystyka będzie..., 2021). Wobec tak wymiernego spadku wskaźników ekonomicznych mechanizmy interwencjonizmu państwowego wydają się nie tylko uzasadnione, lecz wręcz wskazane.

\section{Interwencjonizm państwowy jako regulator procesów ekonomicznych w kryzysie}

Niekorzystnej sytuacji rynkowej powinny przeciwdziałać instrumenty interwencjonizmu państwowego. Współcześnie państwo jako instytucja odgrywa istotną 
rolę w organizowaniu i funkcjonowaniu systemu gospodarki rynkowej. Rola ta sprowadza się do swoistego kompromisu między zapewnieniem jak najlepszych warunków funkcjonowania danego rynku (na przykład rynku usług turystycznych) a koniecznością korygowania negatywnych skutków oddziaływania mechanizmu rynkowego związanego z nadmiernym bezrobociem, nadmierną rozpiętością dochodów czy z kryzysem, którego bardzo dobrym przykładem jest pandemia COVID-191.

Mechanizmy interwencjonizmu państwowego po raz pierwszy wprowadził J.M. Keynes jako odpowiedź na wielki kryzys światowy w latach trzydziestych XX wieku. Państwo, stosując instrumenty polityki pieniężnej, fiskalnej czy finansowej, może wpływać bezpośrednio na mechanizmy rynkowe. Wśród ekonomistów do dzisiaj istnieją spory o realne efekty różnych form interwencjonizmu, zwłaszcza współcześnie, na tle globalizacji, europeizacji, społeczno-ekonomicznych przemian czwartej rewolucji cyfrowej. Jak stwierdza C. Berry, krytycznie nastawieni ekonomiści (Davies, 2014; Mirowski, 2013; Schmidt, Woll, 2014; Stahl, 2019) powszechnie akceptują obecnie przekonanie, że „interwencje państwa na dużą skalę w gospodarce kapitalistycznej są nie tylko zgodne z neoliberalizmem, ale mogą być nawet jedną z jego cech definicyjnych (w przeciwieństwie do klasycznego liberalizm)" (Berry, 2021, 1).

Patrząc na skalę Unii Europejskiej, z jednej strony nasuwa się pytanie: czy UE z jej silną gospodarką i wspólną walutą ma się przekształcić w rodzaj protekcjonistycznej i interwencjonistycznej fortecy wobec pozostałego świata? (Poździoch, 2014; Dani, 2018). Z drugiej strony obserwuje się, iż „od 1980 r. [...] we wszystkich istotnych wskaźnikach (jak: wydatki, dotacje, przedsiębiorstwa państwowe, regulacje, opodatkowanie kapitału) interwencja rządu została zmniejszona w krajach OECD” (Zohlnhöfer et al., 2018, 535).

Jak podkreśla J. Paśnik (2019):

w krajach demokratycznych kwestia ta jest uregulowana na dwóch poziomach — poziomie ogólnym, określającym zasady ustroju gospodarczego i granic ingerencji państwa w gospodarkę oraz poziomie rozwiązań instytucjonalnych (ustawowych). O ile ustawodawca deklaruje wprawdzie przestrzeganie konstytucyjnych zasad ustroju gospodarczego, o tyle istota szeregu aktów ustawodawczych w istotny sposób narusza te zasady.

W tabeli 2 przedstawiono narzędzia korygowania działania mechanizmu rynkowego przez państwo będące jednocześnie argumentami zwolenników aktywnej roli państwa (Jankowski, 2004).

1 Odrębnym zagadnieniem jest konieczność zapewnienia przez państwo efektywnego wykonywania usług publicznych, tworzenia infrastruktury gospodarczej i wynikająca z tego konieczność zapewnienia na ten cel określonych środków finansowych. 
Tabela 2. Narzędzia korygowania działań mechanizmu rynkowego przez państwo

\begin{tabular}{|c|c|c|c|}
\hline \multicolumn{2}{|c|}{$\begin{array}{c}\text { Niedoskonałości } \\
\text { „niewidzialnej ręki” rynku }\end{array}$} & Metody interwencji państwa & $\begin{array}{l}\text { Przykłady działań interwen- } \\
\text { cyjnych państwa }\end{array}$ \\
\hline \multirow{3}{*}{ 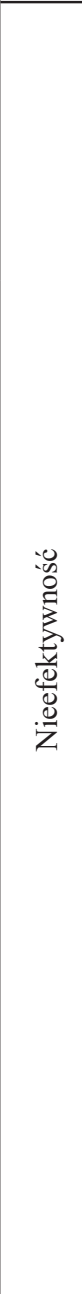 } & $\begin{array}{l}\text { — mechanizm rynkowy } \\
\text { jest zupełnie bezradny } \\
\text { wobec działań monopo- } \\
\text { listycznych i dominacji } \\
\text { korporacji ponadna- } \\
\text { rodowych na różnych } \\
\text { rynkach }\end{array}$ & $\begin{array}{l}\text { — interwencja na rynkach } \\
\text { — wzmacnianie systemu } \\
\text { obiegu informacji } \\
\text { — usuwanie barier } \\
\text { wejścia/wyjścia z/na rynki } \\
\text { — podział monopoli }\end{array}$ & $\begin{array}{l}\text { — ustawodawstwo antymo- } \\
\text { nopolowe } \\
\text { - zwalczanie monopoli, } \\
\text { karteli }\end{array}$ \\
\hline & $\begin{array}{l}\text { — rynek nie potrafi zli- } \\
\text { kwidować negatywnych } \\
\text { efektów zewnętrznych, } \\
\text { w tym pandemii }\end{array}$ & $\begin{array}{l}\text { — interwencje na rynkach } \\
\text { — wprowadzanie ograni- } \\
\text { czeń swobody działalności } \\
\text { przedsiębiorstw } \\
\text { — system kar za naruszanie } \\
\text { środowiska naturalnego, } \\
\text { ustawodawstwa pandemicz- } \\
\text { nego }\end{array}$ & $\begin{array}{l}\text { - wprowadzanie przepisów } \\
\text { dotyczących ochrony środo- } \\
\text { wiska naturalnego czy stanu } \\
\text { epidemicznego }\end{array}$ \\
\hline & $\begin{array}{l}\text { — gospodarka rynkowa } \\
\text { nie dostarcza w wy- } \\
\text { starczającej ilości dóbr } \\
\text { publicznych (ochrona } \\
\text { zdrowia i środowiska } \\
\text { naturalnego, pomoc } \\
\text { społeczna, edukacja, } \\
\text { obronność państwa, bez- } \\
\text { pieczeństwo obywateli). } \\
\text { Gospodarka nie dostar- } \\
\text { cza dóbr prywatnych } \\
\text { (usług turystycznych) }\end{array}$ & $\begin{array}{l}\text { — pomoc publiczna, subsy- } \\
\text { diowanie działalności } \\
\text { w tych dziedzinach lub zle- } \\
\text { canie ich instytucjom pub- } \\
\text { licznym czy prywatnym } \\
\text { — pobudzanie rozwoju infra- } \\
\text { struktury turystycznej } \\
\text { — tworzenie warunków do } \\
\text { modernizacji bazy material- } \\
\text { nej turystyki, pobudzanie } \\
\text { działań o charakterze pro- } \\
\text { efektywnościowym } \\
\text { — gwarancje bankowe } \\
\text { i ubezpieczenia } \\
\text { — zasady zatrudniania i wy- } \\
\text { nagradzania pracowników } \\
\text { itp. }\end{array}$ & $\begin{array}{l}\text { — budowa i rozbudowa infra- } \\
\text { struktury drogowej } \\
\text { — finansowanie dóbr publicz- } \\
\text { nych czy prywatnych } \\
\text { — subwencjonowanie kon- } \\
\text { kretnych branż (np. turystyki) } \\
\text { - tarcze antykryzysowe, } \\
\text { finansowe, bony i świadczenia } \\
\text { pieniężne, i inne mechanizmy } \\
\text { wsparcia przedsiębiorców czy } \\
\text { konsumentów }\end{array}$ \\
\hline 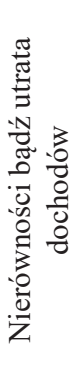 & $\begin{array}{l}\text { - gospodarka rynkowa } \\
\text { rodzi nadmierne dys- } \\
\text { proporcje dochodowe } \\
\text { między poszczególnymi } \\
\text { ludźmi, grupami ludzi } \\
\text { i regionami } \\
\text { — kryzysy powodują } \\
\text { nadmierną utratę docho- } \\
\text { dów w wyniku kryzysów } \\
\text { gospodarczych }\end{array}$ & $\begin{array}{l}\text { — redystrybucja dochodów, } \\
\text { instrumenty polityki fiskal- } \\
\text { nej (zwolnienia i redukcje } \\
\text { podatkowe, obniżona stopa } \\
\text { podatku VAT, gwarancje } \\
\text { i poręczenia itp.) }\end{array}$ & $\begin{array}{l}\text { — progresja podatkowa, sy- } \\
\text { stem zasiłków i transferów } \\
\text { społecznych } \\
\text { - tarcze antykryzysowe, } \\
\text { finansowe, bony i świadczenia } \\
\text { pieniężne i inne mechanizmy } \\
\text { wsparcia przedsiębiorców czy } \\
\text { konsumentów }\end{array}$ \\
\hline
\end{tabular}




\begin{tabular}{|c|c|c|c|}
\hline 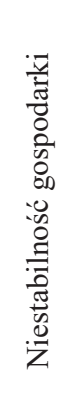 & $\begin{array}{l}\text { — w gospodarce ryn- } \\
\text { kowej występują cykle } \\
\text { koniunkturalne, co } \\
\text { prowadzi do kryzysów, } \\
\text { wahań podstawowych } \\
\text { agregatów makroeko- } \\
\text { nomicznych takich, jak } \\
\text { PKB, produkcja, bezro- } \\
\text { bocie, inflacja } \\
\text { — pandemie również } \\
\text { wywołuja kryzysy }\end{array}$ & $\begin{array}{l}\text { — wpływanie stabilizacyjne } \\
\text { polityki makroekonomicznej } \\
\text { i mikroekonomicznej }\end{array}$ & $\begin{array}{l}\text { - ulgi w systemie podatko- } \\
\text { wym dla inwestorów, instru- } \\
\text { menty polityki fiskalnej i pie- } \\
\text { niężnej } \\
\text { - bony turystyczne } \\
\text { (świadczenia pieniężne } \\
\text { niewypłacane w gotówce) } \\
\text { - tarcze antykryzysowe } \\
\text { i inne mechanizmy wsparcia } \\
\text { przedsiębiorców }\end{array}$ \\
\hline
\end{tabular}

Źródło: opracowanie własne na podstawie: Kościelecki et al., 2015.

Z kolei przeciwnicy interwencji państwa w gospodarce odrzucają argumenty zwolenników aktywnej polityki państwa i przeciwstawiają im kontrargumenty, takie jak (Górka et al., 2020, s. 4-6):

1. państwo zakłóca mechanizmy dostosowawcze gospodarki rynkowej, dzięki którym rynek samodzielnie doprowadza gospodarkę do równowagi;

2. interwencja państwa ogranicza wolność gospodarczą jednostek i grup ludzkich;

3. biurokracja państwowa nie jest zdolna do podejmowania trafnych i skutecznych decyzji, albowiem informacje są najczęściej niepełne i spóźnione. Brakuje też odpowiedzialności za podejmowane decyzje. Ponadto aparat państwowy jest podatny na korupcję;

4. interwencja państwa zakłóca procesy konkurencji, a zwłaszcza układ cen, dając tym samym fałszywe sygnały rynkowe, podczas gdy cena jest najlepszym nośnikiem informacji.

Obecnie formy interwencji państwa w mechanizm rynkowy to głównie: ceny minimalne, ceny maksymalne, wsparcie finansowe podmiotów gospodarczych (subwencje, dotacje, tarcze antykryzysowe i finansowe), wprowadzanie nowych czy modyfikacja istniejących podatków, bony turystyczne itp. Analizując opisywane uwarunkowania, impas wywołany pandemią COVID-19 pokazał jednoznacznie, że bez aktywnej roli państwa walka z kryzysem byłaby niemożliwa. Uruchomiono specjalną stronę Komisji Europejskiej na temat działań UE w związku z pandemią COVID-19: https://ec.europa.eu/info/live-work-travel-eu/ health/coronavirus-response_pl. Wprowadzanie opisywanych mechanizmów interwencji państwowych na świecie stało się sposobem na przeciwdziałanie tak dynamicznym, negatywnym następstwom owej sytuacji. Wymienione instrumenty, zwłaszcza bony i tarcze antykryzysowe, są narzędziami polityki turystycznej prowadzonej we współczesnych gospodarkach, co będzie kolejnym przedmiotem rozważań. 


\section{Interwencjonizm państwowy w polityce turystycznej}

Polityka turystyczna państwa jest to działalność polegająca na określaniu celów ekonomicznych, politycznych, społecznych i kulturalnych związanych z rozwojem turystyki, uzyskiwaniu wszechstronnych pozytywnych efektów wynikających $\mathrm{z}$ istnienia popytu i podaży, dążeniu do zaspokojenia potrzeb społecznych w zakresie uprawiania turystyki (Panasiuk, 2012, 289). Stosowanie przedstawionych instrumentów polityki turystycznej w czasie pandemii COVID-19 jest zgodne ze standardami obowiązującymi na globalnym rynku (dla przykładu we Włoszech: dekret Cura Italia (Uzdrowić Włochy) bony żywnościowe, wydłużenie urlopów wychowawczych czy zwolnienia z płacenia składek zdrowotnych, ulgi dla małych i średnich przedsiębiorców; zapewnienie płynności finansowej włoskim firmom pogrążonym w kryzysie; 200 mld euro na wsparcie rynku wewnętrznego i $200 \mathrm{mld}$ euro na wzmocnienie eksportu) (https://finanse.rankomat.pl/poradniki/ polska-tarcza-antykryzysowa).

Do stosowanych form pomocy państwa w gospodarce możemy zaliczyć następujące instrumenty: dotacje, ulgi podatkowe dla sektora prywatnego, pomoc $\mathrm{w}$ formie dotacji lub pomocy zwrotnej w ramach programów operacyjnych, wprowadzenie instrumentów gwarancyjnych i preferencji kredytowych umożliwiających przedsiębiorstwom zachowanie płynności, wsparcie sektora finansowego, dopłaty do oprocentowania kredytów bankowych, dopłaty do wynagrodzeń i w zakresie składek na ubezpieczenie społeczne (Pandemia COVID-19..., 2020, 19-20). Rysunek 2 ilustruje stosowane wsparcie w krajach OECD, spośród których najczęściej wykorzystywane instrumenty interwencjonizmu to bezpośrednie wsparcie dla przedsiębiorców, a najrzadziej - zmiany w przepisach dotyczących zwolnień z pracy.

Analizując konkretnie rynek turystyczny, oprócz opisanych uprzednio regulacji Unia Europejska wprowadziła wiele instrumentów wsparcia dla przedsiębiorców i pracowników ukierunkowanych tylko na ten sektor, między innymi: wsparcie płynności finansowej, ulgi podatkowe, złagodzenie zasad pomocy państwa, tymczasowe zawieszenie przepisów UE dotyczących przydziałów czasu na start lub lądowanie (Zmiany w branży turystycznej..., 2020). Parlament UE 19 czerwca 2020 roku przegłosował rezolucję w sprawie transportu i turystyki, apelując o dalsze działania wspierające małe i średnie przedsiębiorstwa dotknięte kryzysem oraz do uruchomienie specjalnej linii budżetowej, aby zasilić sektor (COVID-19 and the tourism sector..., 2020). Co więcej, Unia Europejska podjęła też działania służące ochronie podróżujących — zaktualizowała wytyczne dotyczące praw pasażerów oraz dyrektywę w sprawie imprez turystycznych; uruchomiła program Unijnego Mechanizmu Ochrony Ludności, by pomóc powrócić do swoich krajów dziesiątkom tysięcy turystów zatrzymanych za granicą z powodu wybuchu pandemii (Zmiany w branży turystycznej..., 2020). Kolejnym istotnym rozwiązaniem było wsparcie finansowe przyznawane bezpośrednio konsumentom 
jako rekompensata za anulowane, a już opłacone rezerwacje i bilety. Poniesione koszty, zamiast operatorów turystycznych, zwracało państwo. Ponadto zintensyfikowano współpracę komisji z państwami członkowskimi, organami międzynarodowymi i głównymi stowarzyszeniami zawodowymi w UE w celu monitorowania skutków kryzysu dla branży turystycznej i koordynowania działań wspierających (Kudelska, 2020; https://ec.europa.eu/commission/presscorner/detail/p1/IP_20_459; https://ec.europa.eu/commission/presscorner/detail/pl/ip_20_496).

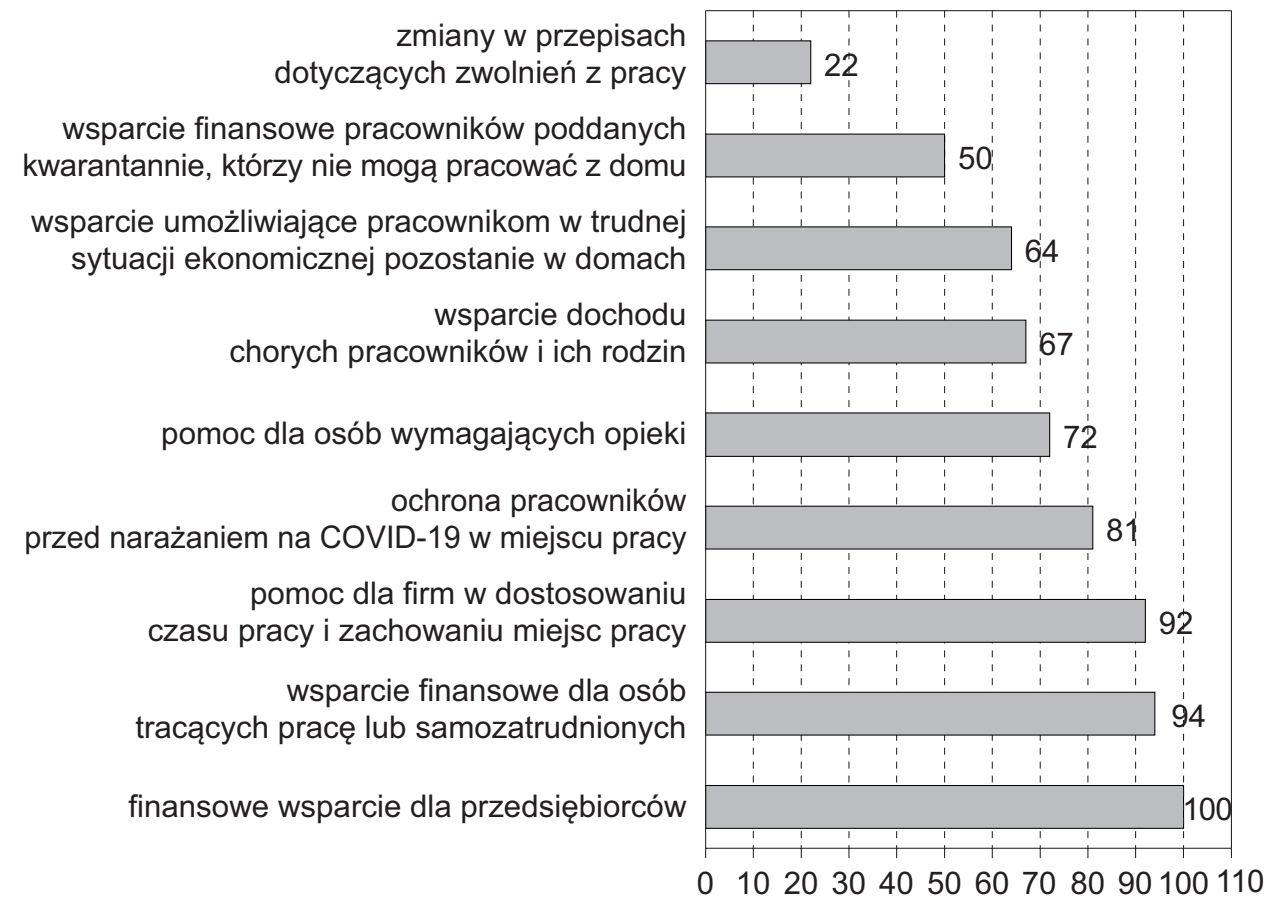

Rysunek 2. Najczęściej stosowane mechanizmy wsparcia w krajach OECD

Źródło: OECD, 2020.

\section{Bon turystyczny i tarcze antykryzysowe}

Jednym z narzędzi polityki turystycznej jest bon turystyczny stosowany w Polsce od 2020 roku. Bon turystyczny jest formą wsparcia dla branży turystycznej oraz dla polskich rodzin w związku z trudną sytuacją gospodarczą wywołaną epidemią COVID-19. Za pomocą bonu można zapłacić za usługi hotelarskie lub imprezy turystyczne w Polsce. Przysługuje na każde z 6,5 mln polskich dzieci. Do wykorzystania jest kwota 500 zł (1000 zł dzieciom z orzeczeniem o niepełnosprawności). Bon turystyczny jest ważny do końca marca 2022 roku (Widomski, 2020). Do początku 
lipca 2021 roku do programu zgłosiło się ponad 21,4 tys. podmiotów turystycznych. Bon turystyczny nie podlega wymianie na gotówkę ani inne środki płatnicze.

Pomysł bonu turystycznego narodził się w Wenezueli. Działa on tam obok innych bonów (bon „na karnawał”, święta Bożego Narodzenia i Trzech Króli, bon z okazji Dnia Pracy, Dnia Wszystkich Świętych, Dnia Matki, Dnia Niepodległości, bon dla dzieci i młodzieży (do lat 18), emerytów i osób w podeszłym wieku) (https://serwisy.gazetaprawna.pl/turystyka/artykuly/1485106,bon-turystyczny-w-wenezueli.html). Pierwsze skutki działania bonu w Polsce są następujące: część przedsiębiorców branży turystycznej wyszła z „szarej strefy”, następuje dalsze ograniczanie ubóstwa, a także — ze względu na „krajowy” charakter bonu — rośnie zainteresowanie destynacjami turystycznymi w Polsce.

Innym instrumentem wsparcia w czasie kryzysów są tarcze antykryzysowe. Pakiet ustaw składający się na tarcze antykryzysowe proponuje wiele rozwiązań o charakterze horyzontalnym, wśród nich powstała Tarcza Turystyczna, skierowana bezpośrednio do branży turystycznej. Przepisy tych ustaw przewidują zapewnienie preferencyjnych pożyczek na zwroty wpłat klientów organizatorów turystyki, specjalny fundusz, w którym będą gromadzone pieniądze dla turystów i organizatorów wycieczek za odwołane imprezy turystyczne, postojowe oraz zawieszenie składek ZUS dla całej branży turystycznej. Tarcza 4.0 to z kolei rozwiązanie pozwalające na: czasowe przepisy antyprzejęciowe dla ochrony polskich firm przed wykupem przez inwestorów spoza Europy i OECD, wsparcie budżetów samorządów, ułatwienia dotyczące przetargów, dopłaty z budżetu państwa do oprocentowania kredytów bankowych dla firm, wakacje kredytowe dla tych, którzy po 13 marca 2020 roku stracili pracę lub główne źródło dochodu, wsparcie utrzymania miejsc pracy przez dostosowanie rynku pracy do wyzwań spowodowanych przez COVID-19, ułatwienia podatkowe, w tym prawo do odliczania darowizn na rzecz między innymi domów samotnej matki, noclegowni, schronisk dla osób bezdomnych czy domów pomocy społecznej. W tych przepisów mogą korzystać podmioty działające również na rynku usług turystycznych.

Całkowita wartość wsparcia w ramach Tarczy Antykryzysowej w Polsce to około 312 mld PLN². Gotówkowy komponent rządowy stanowi wartość około 67 mld PLN (2,9\% PKB). Składają się na niego wydatki budżetu państwa, ZUS-u i funduszy celowych:

a) płynnościowy komponent rządowy o wartości blisko 75,5 mld zł (około 3,3\% PKB). Tworzą go: wakacje kredytowe, odroczone daniny, a także finansowanie płynnościowe w postaci kredytów i kapitału głównie z wykorzystaniem instrumentów finansowych Grupy Polskiego Funduszu Rozwoju (PFR, BGK, KUKE, ARP);

b) pakiet płynnościowy NBP o wartości mniej więcej 70 mld zł, który zapewni niezbędną płynność i warunki kredytowe;

2 Od początku pandemii COVID-19. 
c) Tarcza Finansowa (100 mld zł) - program wsparcia obsługiwany przez Polski Fundusz Rozwoju, skierowany do mikrofirm (zatrudniających co najmniej jednego pracownika) oraz małych, średnich i dużych przedsiębiorstw (w sumie do około 670 tys. polskich przedsiębiorców).

\section{Wnioski}

Kryzys gospodarczy, który pojawił się w związku z epidemią COVID-19, dostarczył empirycznych dowodów na konieczność stosowania mechanizmów interwencyjnych państwa w określonych sytuacjach. Wskazana w analizie skala spadków wskaźników ekonomicznych branży turystycznej, jako jednej z najbardziej poszkodowanych dynamicznym zmniejszeniem się popytu na usługi, uzasadnia racjonalność wprowadzenia tak licznych, w tym charakterystycznych tylko dla tego sektora, rozwiązań ze strony władz unijnych, rządowych i samorządowych.

Skala kryzysu wskazuje, że pod wpływem pandemii COVID-19 rynek turystyczny się zmienia. Udział turystyki w światowym PKB w 2020 roku — w stosunku do 2019 — zmniejszył się o prawie połowę. W Polsce przychody agentów turystycznych spadły w styczniu 2021 roku, w porównaniu ze styczniem 2020 ro$\mathrm{ku}$, aż o $82 \%$. Zastosowane narzędzia interwencjonizmu mają na celu ochronę turystyki, aby w wyniku zmian nie traciła na znaczeniu w gospodarce. Jak wynika z analizy, w krajach OECD najczęściej stosowanym instrumentem interwencjonizmu było bezpośrednie wsparcie finansowe dla przedsiębiorców, a najrzadziej — zmiany w przepisach dotyczących zwolnień z pracy. W wypadku polskich podmiotów gospodarczych pomoc finansowa, wliczając Polski Fundusz Rozwoju 2.0, pokryła tylko około $15 \%$ ponoszonych przez firmy kosztów stałych, które zostały i tak bardzo zredukowane (Ekspert: turystyka będzie..., 2021). Wsparcie wojewódzkie dla przedsiębiorców w większości nie trafiło do firm stricte turystycznych, ale do przedstawicieli innych usług, niezwiązanych z obsługą turystów (Ekspert: turystyka będzie..., 2021). Dobrym zaś rozwiązaniem jawią się specyficzne, charakterystyczne tylko dla tego sektora gospodarki, mechanizmy (Tarcza Turystyczna, bon turystyczny, cyfrowy Zielony Certyfikat Szczepień itp.). Wdrożenie do systemu bonów turystycznych przyniosło wiele bezpośrednich i pośrednich konsekwencji, jak: wzrost popytu na krajowe usługi turystyczne, zmniejszenie ubóstwa ludności, wychodzenie firm z „,szarej strefy”.

Ze względu na sytuację na świecie i w Europie, która dynamicznie się zmienia w zależności od nasilenia wzrostu zakażeń i zgonów z jednej strony oraz liczby osób zaszczepionych z drugiej (Farzanegan et al., 2020; WTTC, 2021), konieczne jest modyfikowanie na bieżąco regulacji interwencyjnych ze strony państwa. W chwili przygotowywania niniejszej pracy Parlament UE planuje, aby do końca lata 2021 roku wszystkie unijne kraje zaszczepiły przynajmniej 70\% dorosłych mieszkańców (Wolska, 2021C), co przyjmuje się za istotną determinantę wzrostu 
popytu na usługi turystyczne, czyli kondycję firm. Z kolei przedstawiciele branży turystycznej w Polsce proponują zwiększenie do 16 mld zł kwoty przeznaczonej dla sektora turystyki w Krajowym Planie Odbudowy (Ekspert: turystyka będzie..., 2021).

Należy pamiętać, że tworzone na bieżąco światowe prognozy są modyfikowane zgodnie $\mathrm{z}$ aktualną sytuacją epidemiczną, która jest zróżnicowana przestrzennie. Po obecnym sezonie wakacyjnym (2021) przewidywana jest kolejna, czwarta fala pandemii. Co więcej, jak twierdzą badacze we francuskim Centrum Narodowym Badań Naukowych (CNRS) (Świat mogą czekać kolejne pandemie..., 2021), możliwe są kolejne pandemie i państwa muszą być do tego przygotowane. $\mathrm{Z}$ jednej strony będzie to się wiązać $\mathrm{z}$ dostępnością aktualizowanych na bieżąco, dostosowanych do potrzeb mechanizmów interwencyjnych, z drugiej zaś ze zmianami po stronie samych podmiotów turystycznych. Panuje pogląd, że zaistniałą sytuację należy traktować jako okazję do modernizacji turystyki w UE, aby stała się ona, jak wskazują wyniki badań literaturoznawczych — przyjazna dla środowiska i odpowiedzialna społecznie (COVID-19 and the tourism sector..., 2020; Koh, 2020).

\section{Bibliografia}

Berry, C. (2021). The substitutive state? Neoliberal state interventionism across industrial, housing and private pensions policy in the UK. Sage Journal. Financialization. State and Policy. Competition \& Change, $0(0) 1-24$.

Branża turystyczna w Polsce. Obraz sprzed pandemii. (2020). Raport Polskiego Instytutu Ekonomicznego, Warszawa.

Dani, M. (2018). The EU Social Market Economy and the Law. London: ImprintRoutledge.

Davies, W. (2014). The Limits of Neoliberalism: Authority, Sovereignty and the Logic of Collective Action. London: SAGE.

Farzanegan, R.M., Gholipour, H.F., Feizi, M., Nunkoo, R., Andargoli, E.A. (2020). International Tourism and Outbreak of Coronavirus (COVID-19): A Cross-Country Analysis. Journal of Travel Research. DOI: 10.1177/0047287520931593.

Górka, K., Łuszczyk, M., Thier, A. (2020). Ujemny podatek dochodowy jako neoliberalne rozwiązanie dla polityki społecznej. Barometr regionalny, 14 (4), 4-6.

Jankowski, S. (2004). Kilka refleksji na temat roli państwa w gospodarce polskiej. Acta Scientifica Academiae Ostroviensis, 17, 5-15.

Koh, E. (2020). The end of over-tourism? Opportunities in a post-COVID-19 world. International Journal of Tourism Cities. Data dostępu: 1.06.2021, https://www.emerald.com/insight/content/ doi/10.1108/IJTC-04-2020-0080/full/html.

Kościelecki, L., Stańczyk, K., Tomczyk, M. (2015). Rola państwa w gospodarce rynkowej finansowanie wydatków obronnych. Inżynieria Bezpieczeństwa Obiektów Antropogenicznych, 1, $22-28$.

Marques Santos, A., Madrid, C., Haegeman, K., Rainoldi, A. (2020). Behavioural changes in tourism in times of COVID-19: Employment scenarios and policy options. Luxembourg: Publications Office of the European Union. DOI:10.2760/00411, JRC121262.

Mirowski, P. (2013). Never Let a Serious Crisis Go to Waste: How Neoliberalism Survived the Financial Meltdown. London: Verso. 
Panasiuk, A. (2012). Polityka turystyczna w oddziaływaniu na branżę turystyczną. Prace Naukowe Uniwersytetu Ekonomicznego we Wrocławiu, 259, 285-295.

Pandemia COVID-19. Sytuacja w wybranych krajach europejskich. (2020). Warszawa: Biuro Analiz, Dokumentacji i Korespondencji. OT-680, 19-20.

Paśnik, J. (2019). Selected Aspects of The Economic and Normative Conditions of the Principles of the Economic System in the Constitution of the Republic of Poland of 1997 (PL). Przeglad Prawa Publicznego, 9, 61-77.

Poździoch, S. (2014). Europejski model społeczeństwa i gospodarka rynkowa jako wyzwania dla XXI wieku. W M. Grzybowski (red.), Państwo demokratyczne, prawne i socjalne. Studia spoteczne, polityczne i ekonomiczne. Kraków: UJ, Krakowska Akademia Frycza Modrzewskiego, $4,525-544$.

Schmidt, V.A., Woll, C. (2014). The state: the bête noire of neoliberalism or its greatest conquest? In V.A. Schmidt, M. Thatcher (eds.), Resilient Liberalism in Europe's Political Economy. Cambridge: Cambridge University Press, 112-142.

Stahl, R.M. (2019). Economic liberalism and the state: Dismantling the myth of naïve laissez-faire. New Political Economy, 24 (19), 473-486.

UNWTO. (2011). Tourism Towards 2030 Global Overview.

UNWTO. (2020A). International Tourism Highlights, 2020 Edition.

UNWTO. (2020B). World Tourism Barometer, May 2020 - Special focus on the Impact of COVID-19.

Widomski, M. (2020). Turystyka krajowa a pandemia. Poszerzamy Horyzonty, 21 (1), 771-779.

WTTC. (2020). Global Economic Impact \& Trends 2020.

WTTC. (2021). Travel \& Tourism: Economic Impact 2021, April 2021.

Zelek, A. (2020). V jak Victoria czy L jak lichota - czyli globalna gospodarka po koronakryzysie, Firma i Rynek - Zeszyty Naukowe ZPSB, 2 (58).

Zelek, A. (2021). COVID - czarny łabędź koniunktury w perspektywie najbliższych 2 lat (rozważania słuchaczy Programu MBA). Firma i Rynek - Zeszyty Naukowe ZPSB, 1 (59).

Zohlnhöfer, R., Engler, F., Dümig, K. (2018). The Retreat of the Interventionist State in Advanced Democracies. British Journal of Political Science, 48 (2), 535-562. DOI: 10.1017/ S0007123416000454.

\section{Źródła internetowe}

www1. COVID-19 and the tourism sector. (2020). European Parliament Briefing. Data dostępu: 1.06.2021, https://www.europarl.europa.eu/news/pl/headlines/society/20200429STO78175/ koronawirus-wsparcie-ue-dla-turystyki.

www2. Ekspert: turystyka będzie już zupełnie inna — wywiad z J. Kowalczykiem. (2021). Onet.pl. Data dostępu: 28.07.2021, https://wiadomosci.onet.pl/kielce/koronawirus-co-dalej-z-branza-turystyczna-ekspert-nie-ma-watpliwosci/f99ny29.

www3. Gołembski, G. (2020). Turystyka w czasach pandemii. Data dostępu: 28.07.2021, https:// www.wot.org.pl/wp-content/uploads/Turystyka-w-czasach-pandemi_23.06.2020.pdf.

www4. GUS (2020). Turystyka w Polsce w obliczu pandemii COVID-19. Data dostępu: 28.07.2021,https://stat.gov.pl/files/gfx/portalinformacyjny/pl/defaultaktualnosci/5494/13/1/1/ turystyka_w_polsce_w_obliczu_pandemii_covid-19.pdf.

www5. GUS (2021). Turystyka w 2020 roku. Warszawa. Data dostępu: 28.07.2021, https://stat.gov. pl/obszary-tematyczne/kultura-turystyka-sport/turystyka/turystyka-w-2020-roku,1,18.html. www6. Data dostępu: 4.06.2021, https://ec.europa.eu/commission/presscorner/detail/pl/IP_20_459. www7. Data dostępu: 4.06.2021, https://ec.europa.eu/commission/presscorner/detail/pl/ip_20_496. www8. Data dostępu: 19.07.2021, https://ec.europa.eu/info/live-work-travel-eu/health/coronavirus-response_pl.

Ekonomia - Wroclaw Economic Review 27/3, 2021

(C) for this edition by CNS 
www9. Data dostępu: 16.06.2021, https://finanse.rankomat.pl/poradniki/polska-tarcza-antykryzysowa.

www10.Datadostępu:15.06.2021,https://serwisy.gazetaprawna.pl/turystyka/artykuly/1485106,bon-turystyczny-w-wenezueli.html.

www11. Kudelska, A. (2020). Koronawirus w UE - Komisja Europejska określa skoordynowaną europejską reakcję na skutki gospodarcze pandemii COVID-19. Departament Wsparcia Przedsiębiorczości PARP. Enterprise Europe Network. Data dostępu: 31.05.2021, https://www. parp.gov.pl/component/content/article/59138:koronawirus-w-ue-komisja-europejska-okresla-skoordynowana-europejska-reakcje-na-skutki-gospodarcze-pandemii-COVID-19.

www12. OECD (2020). Supporting people and companies to deal with the Covid-19 virus: Options for an immediate employment and social-policy response. ELS Policy Brief on the Policy Response to the Covid-19 Crisis. Data dostępu: 11.06.2021, http://oe.cd/covid19briefsocia.

www13. Świat mogą czekać kolejne pandemie. (2021). Business Insider. Data dostępu: 1.06.2021, https://businessinsider.com.pl/wiadomosci/swiat-moga-czekac-kolejne-pandemie-ekspert-wymienia-czynniki-ryzyka/b370mwb.

www14. Wolska, A. (2021A). Koronawirus zabrał $62 \mathrm{mln}$ miejsc pracy w turystyce. Euractive. pl. Data dostępu: 29.05.2021, https://www.euractiv.pl/section/gospodarka/news/koronawirus-zabral-62-mln-miejsc-pracy-w-turystyce/.

www15. Wolska, A. (2021B). UNWTO: Branża turystyczna straciła w 2020 r. przez koronawirusa 1,3 bln dolarów. Euractive.pl. Data dostępu: 26.05.2021, https://www.euractiv.pl/section/ gospodarka/news/unwto-branza-turystyczna-stracila-w-2020-r-przez-koronawirusa-13-bln-dolarow/.

www16. Wolska, A. (2021C). Malta jako pierwsza w UE zaszczepiła 70 proc. dorosłych mieszkańców. Euractive.pl. Data dostępu: 30.05.2021, https://www.euractiv.pl/section/bezpieczenstwo-i-obrona/news/malta-szczepienia-unia-europejska-komisja-europejska-wakacje-2021-turystyka-urlop/.

www17. Zmiany w branży turystycznej w związku z epidemią COVID-19, Polski Fundusz Rozwoju. (9.07.2020). Data dostępu: 4.06.2021, https://startup.pfr.pl/pl/aktualnosci/zmiany-w-branzy-turystycznej-w-zwiazku-z-epidemia-covid-19/. 